\title{
Discussion on Task - based Teaching Mode of Computer Aided College English Listening and Speaking
}

\author{
Hongxia Li \\ ${ }^{1}$ Tianjin University of Technology and Education, Tianjin, 300222
}

Keywords: College English, Teaching Mode, Task-based Method

\begin{abstract}
This paper studies how to implement the audiovisual teaching mode in the network environment as an example to build the college English audio-visual class. Based on the analysis of the theory of task - based teaching method, this paper puts forward the task - based language teaching model of college English listening and speaking based on the network environment, based on the existing research results and the characteristics of college English audio - And explores an effective way to reform college English teaching in the information age.
\end{abstract}

\section{Introduction}

The course is a basic course necessary to enhance English listening and speaking. This course uses multimedia voice classroom teaching, with the advantage of multimedia network technology, add a lot of fresh "vivid audio and video materials, including video" audio "text File, trying to achieve multimedia-assisted teaching and teaching process of communication. The application of multimedia technology conforms to the cognitive psychology of students' language learning. Sound "as a whole to change the form of a single language input, multi-channel to increase the input source, trying to create a lively learning environment. The purpose of college English audio-visual course is to improve students' understanding of all kinds of audio-visual materials And oral expression.

\section{The Problems in the Traditional Teaching Mode of English Listening and Speaking Course}

In the multimedia laboratory, each student is facing the computer screen fixed on the desktop, the traditional teaching mode method is single, the teacher to explain the main, students passively accept, ignore the student's initiative. "Even if there is language practice, But also limited to the mechanical repetition of "rote and single-sentence practice; or excessive emphasis on listening training, weakened the cultivation of other skills. Students have fewer opportunities to participate in the classroom, easy to learn in the sense of loneliness, not to mention the cultivation of their learning sense of cooperation.

The traditional teaching mode of the audio-visual classroom did not change the teacher initiative, students passive situation. But the traditional teaching teacher to play voice information into a click on the mouse to play audio and video materials, students sit in front of the computer screen to accept the information, the same lack of two-way communication mode. According to the questionnaire survey, the auditory and audition classroom still adopts the traditional teaching mode, even if the use of multimedia teaching software and courseware for the so-called teaching, but the language environment has not been greatly improved, but the students exposure to a computer After the screen of the separate space, and there is no meaningful communication activities.

\section{College English Audio-Visual Task-based Teaching Model and Its Characteristics}

The organic integration of network multimedia technology and foreign language teaching has promoted the translation of foreign language teaching mode from closed and unidirectional knowledge and skills to open and multi-directional, showing a diversified teaching model. The learning environment based on network multimedia technology has virtual The "open" interactive "collaborative" diversity and so on. Therefore, the college English audio-visual task-based teaching 
model to modern teaching theory and learning theory as the basis, optimize the combination of teachers "student" media teaching environment and other teaching elements, The use of appropriate media technology and different teaching strategies to implement the effective dissemination and presentation of teaching content, and thus achieve good teaching results In this model, the teaching task selection "design" implementation are based on audio-visual learning strategy training as the center, A variety of learning strategies automatically "conscious and integrated application as the goal, highlighting the understanding of information" to maintain and apply skills to strengthen the training, both to help students lay a solid foundation of the language, but also to develop their strong practical application ability, especially Is the ability to hear.

(1) Pre-task stage: through the warm-up activities into the task, that is, activate the background knowledge, to provide new preparation knowledge, and guide learners to establish the task of "the formation of learning and communication.

(2) The stage of the task: to enable learners to complete a task in an independent or cooperative manner, the practice of language communication activities teacher's help and guidance, teachers and students "students and students interaction, to learn new knowledge" to improve Language skills provide opportunities.

(3) The stage after the task: reflection behavior "to deepen the learning stage, so that learners recollection of the task to complete the process, to improve learners learning language skills Advantages of College English Listening and Speaking Task - based Teaching.

Stimulate learners' interest and internal learning motivation, and promote learners to take the initiative to learn. This model focuses on the comprehensive development of people, emphasizes the development of students 'self-potential, attaches importance to the role and strength of emotions and attitudes in learning activities, and emphasizes the ability to cultivate students' interest in learning and learning to meet the needs of students in English communication and interaction. Students use language self-confidence and ability, is conducive to mobilize the enthusiasm of teachers and students in two areas. Students with lower starting points and better learning motivation for students can learn the opportunity to collaborate to complete their tasks.

The authenticity of the task and the situation close to real life is in a variety of real scenarios. The core of the college English task-based teaching method in the multimedia and network environment is the design of the task. The design task should pay attention to the situation that the students provide a natural, relatively real, close to the real life of the students. The language information should be clear, true, And language form to meet the language function and language law, so that it is conducive to students to complete the task. Teaching tasks are no longer rigidly adhere to the books on the text and practice. Teachers on the choice of materials and tasks continue to expand, with the help of network teaching resources to design the required real situation tasks are easier.

Emphasizes doing secondary school, students through the use of language to complete the task, and learn the language in the task, so take full advantage of the unconscious language acquisition process. The biggest difference between task-based teaching and traditional teaching is that it is no longer a teacher to present the language knowledge to the students, but to let the students learn the meaning and form of the language in the rich learning environment by completing the task. The activities are to express the meaning of the main. To express the meaning of the main the participants say and convey the information should be other people do not know is the real communication. Expression of meaning can be achieved through a variety of forms, such as the exchange of information, exchange views, share personal experience, solve the problem.

\section{Advantages of College English Listening and Speaking Task -based Teaching}

According to the characteristics, constituent elements, difficulty factors, design principles, implementation principles and shortcomings of the above-mentioned task-based teaching method in the process of college English audio-visual class-level teaching, combined with the characteristics of the course, the task-based language teaching theory As a guide, the establishment of college English audio-visual network teaching environment system, to build a "four-step \# task teaching model. This model is in the network environment, through the teaching task design, implementation 
and testing to improve student learning methods, Strengthen the students 'self-learning consciousness, cultivate students' autonomous learning and lifelong learning ability, carry forward the spirit of cooperative learning among students, so as to realize the organic combination and complementarity of different language teaching and learning theory.

Under the network environment to carry out the task of language teaching and traditional teaching environment, reading, translation, teaching compared to a great advantage. The traditional teaching environment rarely involves the comprehensive training of language skills, does not encourage students to actively participate in the teaching of all aspects, nor encourage students to actively think, the lack of true meaning of the exchange, which is the students complain about college bilingual boring one of the reasons Restricting the development of college English. Through the establishment of college English audio-visual network teaching system, in the network environment, teaching resources, rich variety of forms, is conducive to stimulate student interest, to provide students with their own personalized learning, not only conducive to classroom teaching, Earth to mobilize students to take the initiative to learn. The system focuses on language input and emphasizes language output. It is composed of a platform and four systems, namely, computer network platform, network resource system, quality monitoring system, cooperative learning system and autonomous learning system.

For the purpose of the mission, we have positioned the goal of college English audio-visual design. College English teaching requirements: College English teaching goal is to develop non-English majors in English comprehensive application ability, especially listening and speaking ability, so that they in the future work and social interaction can be effective in English oral and written information exchange, While enhancing self-learning ability. For the audiovisual course objectives, according to the specific circumstances to develop the corresponding requirements: Listening ability: to understand English lectures, understand the subject is more familiar with the sentence structure is relatively simple, basically no words, the speed is about 60 words per minute short Conversations, conversations, reports and lectures, master their central care, seize the main points and details, and understand the views and attitudes of the speaker. The ability to: the content of the textbook and the appropriate listening material to ask questions and repeat, can use English in general daily conversation, can hear the familiar topic prepared by the brief speech, express the idea is more clear, voice, tone basic correct.

Under the guidance of teaching objectives, the task selection should be related to the subject, it is easy to reflect, diversification and diversity, and tactical training. First, for the theme of the curriculum unit, select the British and American countries of the various real social material; the second is for students at different levels of university select the audio-visual material when the attention speed, vocabulary, length of time and the complexity of background knowledge , And will listen to the type of task in accordance with its ease and the required language skills to be graded; Third, the selection to diversify, reflect the diversity, it is necessary to have political, economic, social, cultural, religious and other materials, but also have the different social class, race, occupation, gender and other materials, so as to train a variety of different skills to enable students to maintain a strong interest in learning; Fourth, the selection of the University should be required at different stages of the required learning strategy training. According to the law of language learning, the lower grade is mainly language input, strengthen the training of memory strategy; appropriate training cognitive strategies, so that students summarize and summarize the knowledge; emotional strategy training and reduce student anxiety, Encourage and get learning help. In the senior year, we mainly focus on self-learning and language output. Therefore, we should focus on cultivating meta cognitive strategies. Students should master the planning strategy, monitoring strategies and evaluation strategies so as to obtain better learning effect.

\section{Conclusion}

The use of the task-based teaching model makes the information technology in the English listening and speaking course integrated into the learning process. This kind of integration is not simply the application of the information technology contained in the course, but in the application to have the 
purpose and the learning content associated with the learner's active learning associated with the pursuit of teaching optimization, Information technology as a learning tool, the information technology and learning environment integration, to achieve the overall greater than part of the sum of the system effect. College English audio-visual task-based teaching model is to achieve the information technology environment from the teacher as the center, simply teach the language knowledge and skills of teaching ideas and practice, to the student-centered" both to teach language knowledge and skills, pay more attention to training.

\section{References}

[1] Wang Dan, Zhang Yi. Application of "tumbling classroom" based on microclass in college English listening and speaking teaching [J]. Journal of Lanzhou Education College, 2017 (01)

[2] Tan Jiaqi, Yang Shengnan. Micro-class in college English translation teaching application research [J]. Shanxi youth, 2017 (03)

[3] Liu Yan. The micro-class teaching in the independent college college English teaching application [J]. Campus English, 2016 (34)

[4] Xu Xiaoli. College English translation teaching theory and skills of penetration [J]. Campus English, 2016 (34)

[5] Yang Xi. The teaching of college English teaching ideas [J]. Modern Economic Information, 2015 (22) 